\title{
Access Anglesey 2018: Lessons from an inclusive field course
}

\author{
Jacqueline J. Houghton ${ }^{1}$, Daniel J. Morgan ${ }^{1}$, Clare E. Gordon ${ }^{1}$, Alison Stokes ${ }^{2}$, Christopher L. Atchison ${ }^{3}$, \\ Trevor D. Collins ${ }^{4}$, Benjamin Craven ${ }^{1}$, and Katy Willis ${ }^{1}$ \\ ${ }^{1}$ School of Earth and Environment, University of Leeds, Leeds, LS2 9JT, UK \\ ${ }^{2}$ School of Geography, Earth and Environmental Sciences, University of Plymouth, PL4 8AA, UK \\ ${ }^{3}$ School of Education and Department of Geology, University of Cincinnati, Cincinnati, Ohio 45221, USA \\ ${ }^{4}$ Knowledge Media Institute, Open University, Milton Keynes, MK7 6AA, UK
}

Correspondence: Jacqueline J. Houghton (j.houghton@leeds.ac.uk)

Received: 18 December 2019 - Revised: 2 July 2020 - Accepted: 10 July 2020 - Published: 14 August 2020

\begin{abstract}
Traditional methods of fieldwork delivery can present learners with a range of physical, cognitive and social challenges which may subsequently hinder their ability to engage effectively with learning. We developed a residential geoscience field course designed to be physically accessible to, and socially inclusive of, a diverse range of learners including those with limited physical mobility and neurodiverse conditions. This paper presents the logistical and pedagogical challenges involved in delivering such a field course. In terms of pedagogic design scheduling, pace and timing, and the ability to access content in multiple ways were critical to ensuring that all students were included in the learning. The most effective mitigations were the simplest and benefitted the whole group. Practical interventions found to support access and inclusion for the benefit of all participants included using an audio tour-guide system to communicate with students at field locations, using a four-wheel drive vehicle to improve access to specific locations, providing alternative exercises such as prepared photomicrographs and rock specimens, providing electronic tablets with suitable apps, and selecting accommodation with accessible common-room spaces, and a dedicated quiet room.
\end{abstract}

\section{Background to the field course}

\subsection{Why run an inclusive field course?}

Fieldwork is an important aspect of educational delivery in many of the subject areas of Geographical, Earth and Environmental Sciences, with particular benefits in terms of seeing the subject holistically (e.g. Boyle et al., 2007; Butler,
2008), and also in terms of the cohesive bonding of a cohort (e.g. Boyle et al., 2007). The challenges and common experiences of fieldwork provide both a bonding experience for a specific cohort of students, and a common series of experiences when students or graduates from different universities meet in a professional context (Butler, 2008; Whitmeyer et al., 2009). Fieldwork can equally pose significant challenges to students with disabilities (Stokes et al., 2019), both in terms of physical barriers (e.g. physical access, physical capability, sensory limitations) but also in terms of less immediately obvious concerns (e.g. sensory and conceptual overload, physical discomfort, social and academic anxiety, or the ability to focus and remain "on task"). With regard to common pedagogic practices in the sector, missing out on fieldwork has direct impacts to students in terms of participation and social interaction, reinforcing a sense of isolation, in addition to the loss of taught components (Stokes and Boyle, 2009).

Under the UK Equality Act (2010) public sector organisations are required to make reasonable adjustments to their services to ensure services are accessible to those with disabilities. The University of Leeds, in common with other UK educational institutions, has an Equality and Inclusion Framework that aims to embed equality into all aspects of university life. In September 2018, University of Leeds staff led an inclusive geological field course, "Access Anglesey", for a diverse group of thirteen students from across the UK, including six students with disclosed disabilities that had limited their opportunities to participate fully in fieldwork at their home universities. The course was delivered as part of the "Embedding and Sustaining Inclusive STEM Practices" project, funded by the UK Government's Office for 
Students, and sought to investigate inclusive approaches to field-based teaching and learning involving students with disabilities. The Access Anglesey field course aimed to explore different methods of adjustment to enable disabled students to engage with fieldwork. In this paper we discuss the learning outcomes from an organisational perspective and evaluate the effectiveness of chosen adjustments.

\subsection{Course rationale and design principles}

The prior expertise of the organising team was centred on virtual fieldwork, using computers to communicate and reinforce aspects of field skills (Houghton et al., 2015). The team initially considered meeting student needs using virtual methods, but this was reconsidered after attending an accessible field course run at a Geological Society of America conference under the auspices of the International Association for Geoscience Diversity (IAGD) (Gilley et al., 2015). The best and least isolating experience for any student is to participate with their peers in the learning community, in as close an experience to a typical field course as is possible; this led the team to place student experience and outcomes at the centre of the course aims.

From a pedagogic perspective, the aims were as follows:

- To offer a cohort of students with diverse abilities an opportunity to experience an inclusive field course

- To demonstrate and raise awareness to student participants and observers that inclusive field teaching is possible and to disseminate best practice in inclusive field course design

- Where possible, to allow a parallel a set of experiences to all student participants whenever possible.

- To run a field course that would enable all the participants to be actively involved in establishing a geological evolution of the Island of Anglesey

The italic terms above have particular nuance in this discussion; we expand this further below.

Inclusive. We use the definition of inclusive learning and teaching as the "ways in which pedagogy, curricula and assessment are designed and delivered to engage students in learning that is meaningful, relevant and accessible to all. It embraces a view of the individual and individual difference as the source of diversity that can enrich the lives and learning of others" (Hocking, 2010).

Possible, parallel and actively involved. We are operating within the framework of United Kingdom disabilities legislation (UK Government Equality Act, 2010). Under this legislation, public sector organisations are required to make reasonable adjustments to their services to ensure services are accessible to those with disabilities. There is the aim in law that universities should take "reasonable adjustments" to accommodate students with disabilities. In designing the field course, we followed the principles laid out in the American Geosciences Institute (AGI) Disability Consensus Statement (2015), notably the development of flexible learning environments and inclusive curricula. We recognised that an identical experience is not always possible, but an equivalent parallel experience is possible. We aimed to give all participants the opportunity to gain a range of insights into the problems of the field such that their experiences are valued and of use, and they feel actively involved with both the group and the field study process.

\section{Field course staff and participants}

\subsection{Field course staff}

The field course staff consisted of two field instructors, two technical support specialists (one for the LAN system (see Sect. 5.2) and one more general technical support), two participant-researchers and two teaching assistants. One of the field instructors, one of the technical support specialists and both participant-researchers had previously either participated in or been involved in the running of accessible field courses (notably those run by the IAGD). Both teaching assistants were volunteers with previous experience of fieldwork on Anglesey. One also had experience of assisting children and adults with disabilities on outdoor activities. The pre-course planning discussed in this paper was undertaken principally by the two field instructors with advice from the participant-researchers. The teaching on the course was undertaken by the instructors and teaching assistants. However, the extensive practical preparations and the undertaking of the field course involved the whole team.

\subsection{Finding and selecting participants}

\subsubsection{Advertising the course}

The field course was advertised as an inclusive course for any undergraduate student studying a Geology (or related) degree at a UK university, particularly those for whom fieldwork is a challenge due to a disability. Participants did not need to have, or identify as having, a disability to attend the course, only to be willing to get involved in exploring different technologies, techniques and methods that assisted inclusion and accessibility in the field. The field course aimed to be about the geology, for people across a spectrum of abilities; it was not about disability. We also encouraged applications from faculty at other institutions to act as "interested observers", to engage with a wider range of experience and to enable direct dissemination of good practice. Other than transport to and/or from Anglesey, costs for all participants were covered by budget of the research project.

The field course was advertised via the Geological Society of London's (GSL) and the IAGD's websites. A flyer was created and distributed via University Geoscience UK 
(UGUK - the organisation representing the Heads of Geoscience departments in the UK), the GSL's Higher Education Network email list and via extensive personal networks between geoscience departments across the UK. A website was created (https://accessanglesey.leeds.ac.uk/, last access: 10 August 2020) which provided details on the course including the geology, planned locations, accommodation, and how to apply.

\subsubsection{Selection of participants}

The application process collected basic information including institution and disability status together with responses to the following extended questions:

- "Describe your interest and experience in Earth sciences. If you have participated in an outdoor Earth science field course, tell us about what you liked or disliked and what you learned." (Student applicants only)

- "Describe your experience in providing accessible instruction for students with disabilities. If you have previously conducted an accessible field-based course, tell us about the content focus, objectives, how it went and what you learned as a result." (Observer applicants only).

- "Describe how your participation in this field course will have an impact on your future efforts." (Both student and observer).

Application forms were first considered without any identifiers (e.g. names and institutions). The applicant's enthusiasm and understanding of the aims of the course were the primary factors in choosing the participants. Initially, several applicants were rejected on the basis that, despite being interested in geological fieldwork, they did not demonstrate an appreciation of the aims of the course. This raised concerns they may not feel able to participate fully should they attend. However, when their applications were looked at with identifiers, we noted this process had effectively screened out applicants who did not have English as a first language. To mitigate this, they were contacted individually, their enthusiasm acknowledged, and they were gently asked to clarify their understanding of what the course involved; all were happy to do so. This outcome gives an additional aspect of considering those taking field courses in a second language.

Limited places meant three of the total applicants were unsuccessful. The decisions taken were difficult, but we offered places to those the project team felt would benefit most by attending the course. Places were offered to, and accepted by, fifteen student participants, although two withdrew before the start of the course. Of the thirteen students who attended the course, four had neurodiverse conditions (e.g. Attention Deficit Hyperactivity Disorder (ADHD), Autism Spectrum Disorder (ASD)) and two had mobility impairments. One student with ASD brought a personal assistant.
Of the student-participants who identified as having a disability, one had never been able to attend a field course, and the majority had been excluded from participating in some of their undergraduate field courses. All had had negative prior field experiences as a result of their disability.

In addition to student participants there were four participant observers from other institutions, one with a mobility impairment. All were geologists, but none had previously experienced a field course designed for inclusivity.

\subsection{Ethical and legal aspects}

As the field course combined both educational and research aspects, a full ethical review was undertaken at the University of Leeds. This ensured that ethical standards were followed in the collection and retention of data, as well as the treatment of the study participants, and that all relevant legislation was followed (e.g. the recently introduced GDPR standards).

The introduction of the UK general data protection regulations (GDPR) during the preparations for the field course proved challenging. As with any new regulation there was the need to fully understand it before implementing it. As students were registered at different universities, the field course existed outside of the usual educational contract and this placed it in legal terrain that had not been previously encountered. To address this legal situation, participants were requested to sign a Statement of Informed Consent in addition to the field course Terms and Conditions. The Statement of Informed Consent covered the nature of the research project, what would be required of participants, how personal data would be handled and anonymised, how long it would be stored for and under what conditions it would be kept. This included giving consent for photography and use of photographs - such images to be used anonymously in awareness-raising and in academic publications.

\subsection{Risk assessments}

Detailed risk assessments were completed for each field locality including the accommodation. These included details on the facilities (or lack thereof) as well as the nature of the terrain and potential hazards. These risk assessments were in line with normal good practise. Individual risk assessments for each participant were considered, however, given the organisers' limited knowledge of each person's needs these individual risk assessments were considered unlikely to be helpful.

\section{Field course design}

For the outcomes to be perceived as credible across the geoscience education community, it was important the course reflected a "normal" undergraduate geology field course, and so the course learning outcomes were centred around establishing a model for the geological evolution of Anglesey. 


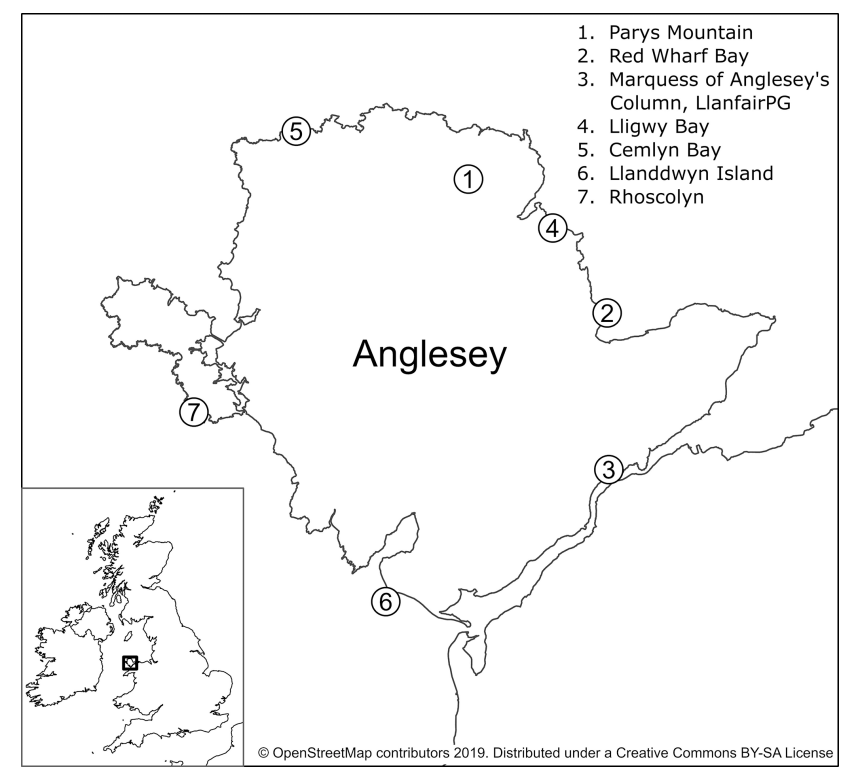

Figure 1. Island of Anglesey with field localities.

This focus on the geology reflects typical sector practice and highlighted the particular challenge of delivering inclusive instruction to accommodate students who are unable physically to get to certain field locations. In alignment with our aim for inclusivity, we invoked the design principles of parallel experience and active involvement. As such, whilst not every student may be able to physically access every locality, every student could be included in the learning experience at every locality.

The Island of Anglesey (Ynys Môn, Fig. 1) lies just off the northwest coast of Wales, UK. We chose it as the location for the field course because the cliffs, beaches and bays of the island's coastline provide extensive outcrops and accessible geological localities to visit, it has good access by road and rail, an established tourist infrastructure and, for the region, a relatively equable climate. It is a "classic" location for field courses for many UK universities because, for a relatively small island $\left(673 \mathrm{~km}^{2}\right)$, it displays a remarkable wealth of geological sites and a long and interesting geological history (Greenly, 1919). It is also an area well known to several of the field course staff.

Field localities were chosen to reflect the intended learning outcome by illustrating particular paleoenvironmental or tectonic features of the geological evolution of Anglesey. Table 1 summarises the localities, their geology, the specific challenges with respect to access, planned mitigations to allow active involvement, alternative exercises for parallel experiences and what actually happened in the field. Tidal restrictions, and a desire to minimise travel times determined the order in which the localities were visited. The longest drive from the accommodation to a locality or between localities was about $40 \mathrm{~min}$. All the localities are publicly accessible; however, four are on privately-owned land and we sought permission from the landowners prior to the field course with respect to taking a four-wheel drive support vehicle on to their land.

The initial aim at each locality was to observe, record, take data readings and interpret the rock units, consistent with the expected abilities of a typical UK geology undergraduate at the end of their first year of study. In addition, at Parys Mountain, we planned to undertake sampling of waters at various points around the mine site for geochemical analysis back at the accommodation in the afternoon and evening. The plan was to visit one or two field sites each day, with short debrief presentations by the instructors and group work in the evenings. A typical undergraduate teaching field course requires justification of cost-time expenditure, with full field days evening work and summative assessment being normal practice. However, recognising working in the field is tiring, particularly for those with a disability we built downtime into the course with shorter field days, limited evening work and no summative assessment.

Finding suitable lodging on Anglesey for the field course participants was a challenge. Our group required accommodation for 26 participants, to include accessible bedrooms and communal areas. A suitable sized hostel was found that was also able to cater to the diverse dietary requirements of the groups. One of the communal rooms was set aside as a "quiet room" for participants who needed a space with minimal distractions to depressurise in.

\section{Active involvement: challenges and mitigations}

Key challenges to active involvement for a student with a disability in a field course are: physical mobility and navigability of field sites; being in an unfamiliar environment without normal support structures; modification of daily routines impacting on physical wellbeing; and, issues with note-taking, and information gathering (Hall and Healey, 2005). To address these, we looked at what mitigations we could put into place to maximize the accessibility of localities visited; effectively communicate information on all aspects of the field course to reduce anxiety around an unfamiliar environment and to allow daily routines to be planned in advance; and, to enable effective data collection in the field.

\subsection{Establishing participants' needs/requirements}

One difficulty specific to this field course was we did not meet the participants in person until the first day of the course. This made pre-course communications particularly challenging. Initial communications with participants were via email and the field course website. The website performed the role of a pre-course handout providing course details, information about the geology of the localities visited, the geological history of Anglesey and summaries of planned 
Table 1. Details of the localities visited. The localities are listed in geological age from oldest to youngest.

\begin{tabular}{|c|c|c|c|c|}
\hline Locality & Geology & Physical challenges & $\begin{array}{l}\text { Planned mitigations and alternative } \\
\text { exercises }\end{array}$ & What actually happened in the field \\
\hline $\begin{array}{l}\text { Llanfairpwllg- } \\
\text { wyngyllgoge- } \\
\text { rychwyrndro- } \\
\text { bwllllantysilio- } \\
\text { gogogoch } \\
\text { (Llanfair PG) }\end{array}$ & $\begin{array}{l}\text { Neoproterozoic } \\
\text { blueschist }\end{array}$ & $\begin{array}{l}\text { Small outcrops in } \\
\text { woodland, accessed via } \\
\text { a rough path. }\end{array}$ & $\begin{array}{l}\text { Wheelchair access with care to lowest } \\
\text { outcrop. Hand specimens and photomi- } \\
\text { crographs with directed questions }\end{array}$ & $\begin{array}{l}\text { All participants were able to access the } \\
\text { lower of the two outcrops in the woods } \\
\text { and record their own data. }\end{array}$ \\
\hline $\begin{array}{l}\text { Llanddwyn Island, } \\
\text { Newborough Forest } \\
\text { Nature Reserve }\end{array}$ & $\begin{array}{l}\text { Neoproterozoic/ } \\
\text { Cambrian pillow } \\
\text { lavas and melange }\end{array}$ & $\begin{array}{l}\text { Outcrops of pillow } \\
\text { lavas on sandy beach. } \\
\text { Outcrops of melange on } \\
\text { rocky/sandy foreshore } \\
\text { on far side of the island, } \\
\text { accessed via a } \\
\text { rough track }\end{array}$ & $\begin{array}{l}\text { Agreed four-wheel drive vehicle ac- } \\
\text { cess to beach with owner Natural Re- } \\
\text { sources Wales (NRW). Live feed sys- } \\
\text { tem for outcrops on the island. Hand } \\
\text { specimens and photomicrographs with } \\
\text { directed questions }\end{array}$ & $\begin{array}{l}\text { The location worked well despite the } \\
\text { rain. All participants were able to col- } \\
\text { lect their own data at the pillow lavas } \\
\text { and the live feed system connected the } \\
\text { four-wheel drive vehicle to the debrief- } \\
\text { ing at the melange outcrop. }\end{array}$ \\
\hline Cemlyn Bay & $\begin{array}{l}\text { Cambrian distal } \\
\text { meta-turbidites, } \\
\text { faulted and folded } \\
\text { on a cm to } \\
\mathrm{m} \text {-scale, and a late } \\
\text { Devensian-aged } \\
\text { drumlin }\end{array}$ & $\begin{array}{l}\text { Large flat lying out- } \\
\text { crops on pebble beach. } \\
\text { No vehicular access } \\
\text { to beach, but outcrops } \\
\text { viewed from track. } \\
\text { Drumlin in cliff further } \\
\text { round the headland. }\end{array}$ & $\begin{array}{l}\text { Live feed system to beach, then set up } \\
\text { relay to drumlin. Hand specimens and } \\
\text { photomicrographs with directed ques- } \\
\text { tions }\end{array}$ & $\begin{array}{l}\text { It was decided not to use the live feed } \\
\text { system as experience on previous days } \\
\text { suggested it would take too long to set } \\
\text { up. Hand specimens worked well (see } \\
\text { main text). It was decided to focus on } \\
\text { the beach location and not visit the } \\
\text { drumlin. }\end{array}$ \\
\hline $\begin{array}{l}\text { Rhoscolyn, Holy } \\
\text { Island }\end{array}$ & $\begin{array}{l}\text { Cambrian proximal } \\
\text { meta-turbidite } \\
\text { sequence folded on } \\
\text { a cm to } \mathrm{km} \text {-scale }\end{array}$ & $\begin{array}{l}\text { Grass and gorse } \\
\text { covered headland. }\end{array}$ & $\begin{array}{l}\text { Four-wheel drive vehicle access (with } \\
\text { permission and via locked gate) and } \\
\text { live feed system for visit; Outcrop pho- } \\
\text { tographs used to analyse two phases of } \\
\text { deformation, plus hand specimens. Vir- } \\
\text { tual landscape for mapping exercise. }\end{array}$ & $\begin{array}{l}\text { The four-wheel drive vehicle was able } \\
\text { to get up close to more localities } \\
\text { than expected and the live feed system } \\
\text { worked well for those localities it could } \\
\text { not get to. }\end{array}$ \\
\hline Rhosneigr & $\begin{array}{l}\text { Ordovician shales } \\
\text { and siltstones } \\
\text { folded on a cm- to } \\
\mathrm{dm} \text {-scale }\end{array}$ & $\begin{array}{l}\text { Foreshore of sandy } \\
\text { beach. }\end{array}$ & $\begin{array}{l}\text { Four-wheel drive vehicle access to parts } \\
\text { of beach. Group work with shared data } \\
\text { for inaccessible areas. }\end{array}$ & $\begin{array}{l}\text { It was recognised, by the second day, } \\
\text { the planned schedule was too full. As } \\
\text { this was the least interesting geologi- } \\
\text { cally of the localities, it was decided not } \\
\text { to visit it. }\end{array}$ \\
\hline $\begin{array}{l}\text { Parys Mountain, } \\
\text { Amlwch }\end{array}$ & $\begin{array}{l}\text { Late Ordovi- } \\
\text { cian/early Silurian } \\
\text { volcanogenic mas- } \\
\text { sive sulphide } \\
\text { deposit }\end{array}$ & $\begin{array}{l}\text { Historic quarry site } \\
\text { with rough tracks. } \\
\text { Main pit only accessi- } \\
\text { ble on foot, although } \\
\text { visible from viewpoint. }\end{array}$ & $\begin{array}{l}\text { Four-wheel drive vehicle access (with } \\
\text { permission and via locked gates) to part } \\
\text { of the site. Live feed system for main } \\
\text { pit. Hand specimens and photomicro- } \\
\text { graphs with directed questions }\end{array}$ & $\begin{array}{l}\text { The live feed system partially worked } \\
\text { from the main pit. Hand specimens } \\
\text { were used when it was not working, but } \\
\text { this led to reduced integration for the } \\
\text { mobility challenged participants. Water } \\
\text { testing worked well and all participants } \\
\text { collected their own samples. }\end{array}$ \\
\hline Red Wharf Bay & $\begin{array}{l}\text { Carboniferous } \\
\text { limestone, sand- } \\
\text { stone and shales } \\
\text { cyclothems with } \\
\text { Carboniferous age } \\
\text { karst features, and } \\
\text { a Miocene(?) aged } \\
\text { beach deposit }\end{array}$ & $\begin{array}{l}\text { Cliff and flat-lying out- } \\
\text { crops on pebble fore- } \\
\text { shore, accessed via a } \\
\text { sandy beach. }\end{array}$ & $\begin{array}{l}\text { Four-wheel drive vehicle access to } \\
\text { beach (with permission via a slipway). } \\
\text { Hand specimens and photomicrographs } \\
\text { with directed questions }\end{array}$ & $\begin{array}{l}\text { The four-wheel drive vehicle was able } \\
\text { to access the beach, which meant addi- } \\
\text { tional samples could be collected and } \\
\text { discussed. Wind issue with the tour } \\
\text { guide system microphone were solved } \\
\text { by broadcasting from inside the vehicle. } \\
\text { The Miocene beach deposit was visited } \\
\text { but in retrospect it was too much to fit } \\
\text { into the location, which led to some lack } \\
\text { of engagement with the outcrop. }\end{array}$ \\
\hline Lligwy Bay & $\begin{array}{l}\text { Devonian sand- } \\
\text { stones and silt- } \\
\text { stones faulted and } \\
\text { folded on a m-scale }\end{array}$ & $\begin{array}{l}\text { Sandy beach and fore- } \\
\text { shore, no vehicular ac- } \\
\text { cess due to quicksand. }\end{array}$ & $\begin{array}{l}\text { With no access to the beach and no } \\
\text { close-up views of the outcrops, the al- } \\
\text { ternative exercise was the planned mit- } \\
\text { igation, to be done in a nearby carpark } \\
\text { with facilities, and long-distance views } \\
\text { to locality. The distance involved was } \\
\text { too great for the live feed system. Out- } \\
\text { crop photographs with directed ques- } \\
\text { tions on the sedimentary features and } \\
\text { palaeoenvironments. Hand specimens } \\
\text { from other Devonian-aged sandstones } \\
\text { for comparative exercise. }\end{array}$ & $\begin{array}{l}\text { The alternative exercises worked quite } \\
\text { well. Key was having a staff member, } \\
\text { familiar with the outcrops, remaining in } \\
\text { the vehicle to allow students to discuss } \\
\text { the work. Facetime/Skype was used via } \\
\text { personal devices with reasonable suc- } \\
\text { cess for some ad hoc discussion on sed- } \\
\text { imentary features. }\end{array}$ \\
\hline
\end{tabular}


activities (https://accessanglesey.leeds.ac.uk/, last access: 10 August 2020).

We offered pre-course video conference calls to all student participants to explore their expectations for the course, their previous field course experiences, and if appropriate, what arrangements or mitigations had worked or not worked for them previously in the field. Experiences for the students with disabilities often involved a history of being unable to fully participate due to mobility problems or fatigue. Many of the challenges students faced matched those identified in the previous section. The students with ASD wanted to know the itineraries for each day in detail in order to minimise anxiety. For another student it was about understanding what was being asked of them in the field as they commonly struggle to remember verbal communications. For others it was about being able manage their energy levels. The overarching message from these calls was that feeling in control of a situation/environment was vital to a positive experience; uncertainty increased anxiety. This reinforced the need for clear communications and detailed information on all aspects of the course.

One very clear lesson from these calls was the need to listen to the students with disabilities and be responsive to their self-advocacy. They all understood what they were capable of, what their limits were, and they had their own suggestions for mitigations.

\subsection{Daily handbooks}

Daily handbooks were designed to address both communications and to aid effective data gathering by providing students with all the information they needed for each day in the field (https://accessanglesey.leeds.ac.uk/publications/ handbooks/, last access: 10 August 2020). To give a sense of time and place, a brief schedule of the day including approximate timings (Fig. 2), an outline map showing the day's localities and a geological time scale indicating the age of the rocks were provided on the front cover of each handout. The handbooks covered each locality in detail with a description of the site (including any facilities), the terrain covered, the geological setting and a briefing on the tasks to be carried out. Our intention was to support effective gathering of field data by providing written details of information that would also be given verbally in the field. The added benefit of the written format is it reduces the need to remember verbal instructions as it can be referred to at any point. Rather than produce one large field handbook, we decided to produce a series of handouts, one for each day. These were provided as printed sheets of A4 paper stapled together in one corner, and as PDFs on the tablets (see Sect. 4.4). This meant each handout was lighter and easier to carry as well as the information within it being easier to find.

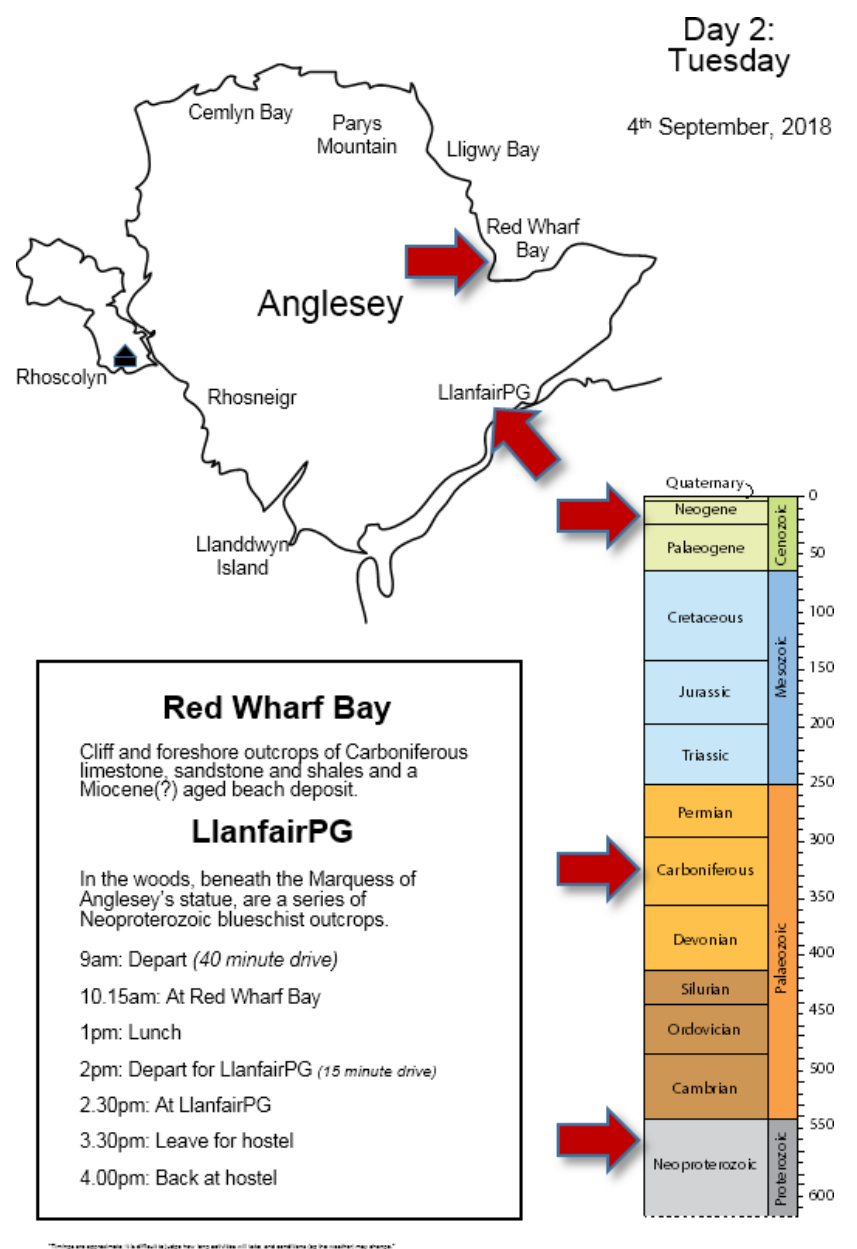

Figure 2. Example of a handout front page showing the schedule and localities for the day, including a brief description and age. Map redrawn from (C) OpenStreetMap contributors 2019. Distributed under a Creative Commons BY-SA License.

\subsection{Audio tour guide system}

Communicating with groups of students in the field can pose interesting challenges, particularly in windy weather or if the location is noisy (e.g. a road cut). The instructor may need to shout in order to be heard, and students can be reluctant to "huddle in". We addressed this issue by using an audio tour guide system to enable everyone to hear information delivered by the instructor. Tour guide systems involve wireless, one-way communication between a presenter and an audience where the presenter has a microphone transmitter and the rest of the party have receivers with headphones/earpieces. The transmitter and receivers are small (about $6 \times 4 \times 2 \mathrm{~cm}$ for the system used) and hung round the neck on a lanyard. The receivers have a standard $2.5 \mathrm{~mm}$ audio jack which will fit most headphones and can be used with them. The kit is stored in a bespoke case which charges the equipment overnight. 


\subsection{Tablets}

Traditionally notebooks are used in the field to collect geological data. While notebooks are highly portable, effectively recording data in a written form in a field setting is challenging for students with Specific Learning Disorders (e.g. dyslexia). Tablets are portable and offer the potential to record information in multiple formats (e.g. type, audio, photographs, annotations etc.). To this end, two iPads and two Android tablets were purchased for the course. These were preloaded with geological and/or field-based apps such as Theodolite on iPad and RockLogger on Android. Notetaking apps such as Google Docs or Pages and drawing apps which allowed the student to annotate over a photograph such as Sketch on Android using a stylus were also provided. The tablets were housed in ruggedised cases.

\subsection{Transport in the field}

Participants were transported to the field localities in selfdrive MPV's (multi-purpose vehicles). A four-wheel drive vehicle was hired to address physical access to sites for those with mobility impairments; the aim being to get them as close as possible to the localities. This required routes to the locality to be checked and permissions from landowners to be gained in advanced. No landowner refused our request. To allow students travelling in the vehicle to sit outside but remain sheltered while field activities took place, we purchased a fisherman's tent, table and chairs.

We also investigated hiring one or more all-terrain wheelchairs. Whilst it is possible to hire some basic generic types of all-terrain or sandy-beach-capable wheelchairs, the costs were high and the logistics of hire, collection and transportation problematic. However, on further investigation we realised each individual wheelchair user has unique requirements and hiring of a wheelchair needed to be done in collaboration with the user. A case on our part of good intentions but with a lack of understanding of what using a wheelchair involves.

\section{Parallel experiences: challenges and mitigations}

We chose field localities for their teaching potential rather than accessibility (Sect. 3). As such, we realised not all participants would be able to physically access all the sites. We also anticipated access to field sites might be hampered for some or all students, for example due to poor weather. To maintain a parallel experience and allow for participants remaining in a vehicle, or at the hostel during the day, we created a series of alternative exercises for most of the localities visited. The challenges of creating parallel fieldwork experiences are: to ensure they are a genuine, meaningful experience comparable with that of working directly at a site, accessible and inclusive in their own right and come as close to meeting the intended learning outcomes of the work as pos- sible. An additional challenge we set was that, where possible, the alternative exercises should enable those participants who cannot visit an outcrop, to contribute unique data to the group.

\subsection{Alternative exercises}

The plan for the alternative exercises offered as parallel experiences was to deliberately give the students completing them access to information and materials not otherwise available to the group. These exercises were set out in guided workbooks produced as a laminated set of A4 and A3 figures, and text. Lamination served as weatherproofing and could be drawn on using erasable OHP pens, enabling students to add annotations, data and interpretations to photographs. The exercises were based around the same lithologies and geological questions as those being studied at the outcrops (examples of the alternative exercises can be found at https:// accessanglesey.leeds.ac.uk/publications/handbooks/, last access: 10 August 2020), and were supplemented with sawn and polished hand specimens, photomicrographs, and photographs of specific features. This approach allowed the students to contribute unique observations and interpretations based on their alternative perspective, and to provide "expertise" based upon that perspective. We then made these materials available to all students in the evening sessions, giving those who had completed the alternative exercises the opportunity to lead discussions and provide informal peer teaching.

\subsection{Live feed system via Local Area Network (LAN)}

We recognised that whilst the four-wheel drive vehicle would be able to get close to or within sight of many of the localities, it would not necessarily allow mobility impaired participants to get up right to the rocks. To mitigate this a live feed system was used to provide a link between the vehicle and those at the outcrop. The live feed system provides a local area network (LAN) over which two-way audio, photographs and a continuous video stream can be broadcast between a hand-held camera at the field locality and remote participants using tablets or laptops. The live feed system is part of a specialist communications toolkit developed by the Open University ERA project (http://projects.kmi.open.ac.uk/era/, last access: 10 August 2020). The equipment for this was supplied by the Open University and configured and maintained in the field by Collins.

The two-way radios were used as a general means to communicate between staff and to communicate with the fourwheel drive vehicle.

\subsection{Virtual landscape}

The Rhoscolyn virtual landscape was designed to replicate the planned in-situ mapping experience to allow those participants unable to undertake mapping in the field the opportunity to map a simulation of the area, and to produce their 
own map and cross section. This was developed as part of the ongoing Virtual Landscape Project at the University of Leeds (https://www.see.leeds.ac.uk/virtual-landscapes/, last access: 10 August 2020) (Houghton et al., 2015).

\section{In the field}

\subsection{Schedule and timing}

By the second day, we acknowledged the original schedule for the field course was too crowded and our days were potentially becoming too long. Consequently, we removed one locality (Rhosneigr) from the schedule and did not visit the drumlin at Cemlyn Bay (see Table 1 for details). Reasons for the time-slippage were:

- The logistics of moving between localities were more time-consuming than we anticipated;

- The unforeseen variety in the degree of geological background knowledge among the students, which meant additional time was needed to explain concepts at some localities;

- Issues with the technology, some which could be overcome, such as a wind shield for the tour guide microphone, and others that represented fundamental limits of the technology such as the battery capacity of the live feed system.

Time keeping also often slipped from that indicated on the daily handout (Sect. 6.2). For most participants, knowing the general plan was more important than the actual times and this was not a problem. However, for the ASD participants, failure to keep to time was a source of frustration; it would have been better to indicate the order of events rather than assign specific times to these. We also found the optimum time for lunch breaks was $45 \mathrm{~min}$ rather than the hour allowed for in the schedule.

The field class was advertised to undergraduate students on a geology (or related) degree programme. All the participants fulfilled the criteria but ranged from one to three years in experience in geology. We had assumed participants would have a level of geological knowledge equivalent to a UK geology undergraduate at the end of their first year of study (for example, they would know how folds form). However, some participants who were taking geology related courses had covered less geology than expected, which led to the need to explain concepts in the field. Whilst this situation would not arise on a field class run by an institution for their own students, for field classes where instructors are less familiar with the participants background we would recommend gaining clearer information on the level of prior knowledge, plus material to bring students up to the required level as needed.

Changes were also made to the evening schedule, which we originally planned to include a short instructor-led discussion on the day's activities, followed by group work. By day three this had evolved into an informal, open session where students could access sample specimens and microscopes/thin sections and engage in one-to-one or small group discussions with students and instructors, as much or as little as they wished. The earlier return from the field and more relaxed approach to evening teaching was of benefit to everyone as it reduced tiredness and allowed everyone to relax and to participate in the social aspects of the course. It provided an opportunity to listen to the student's thoughts and experiences of the day and to respond to any points raised. It was during these discussions the issue of summative versus formative assessment came to light. Students commented they were surprised how liberating the lack of summative assessment felt; that it allowed them the freedom to explore the geology and discuss their ideas without the pressure of getting the "right answer". Summative assessment was also highlighted by the students with disabilities as an additional source of stress on top of the pressures of managing their conditions in the field.

\subsection{Daily handbooks}

A few days into the field course we asked participants for feedback on the daily handouts. Although students reported the handouts were very useful and they were happy with the level of detail there in, it transpired they were only being consulted when first collected in the evening. Handouts were then put into bags to protect them from the weather and forgotten. With discussion we agreed smaller, A5 versions with weatherproof covers would be more practical as they could be carried in coat pockets or kept with notebooks. A4 handouts were also challenging for students with ASDs due to the distracting tendency of the handbook flapping in the wind. As well as reducing the handout size, this can also be mitigated by making handouts available electronically via tablets.

\subsection{Audio tour guide system}

The tour guide system worked effectively in the field and the instructor could be heard by all participants. An additional benefit, particularly appreciated by the students with ASD, was that participants did not have to stand close to the instructor, or to each other, in order to hear. The system also allowed co-instructors to listen in, enabling them to extend conversations with students in an informed way and without contradicting information or instructions.

\subsection{Transport in the field}

Whilst it was originally intended for a mix of participants to travel in the four-wheel drive vehicle, a lack of awareness on the part of the instructors meant we had not appreciated how much space the wheelchairs would take up. As such, carrying more than two passengers in the vehicle was not practical. The four-wheel drive vehicle became a mobile classroom for the students with mobility disabilities, enabling them to get 
closer to the geology at more localities than would otherwise be possible. The fisherman's tent, table and chairs purchased for working outside of the vehicle were not as resilient to the weather conditions as hoped, and these were not used again after the first day. The vehicle proved to be the best and most comfortable place to work and the occupants developed a strong bond, which was a significant aspect of the successful use of the vehicle.

One of the observer-participant's brought their own allterrain wheelchair (with the supporting adapted vehicle required to transport it) and demonstrated its ability to cover all types of terrain visited on the course. As discussed in Sect. 4.5, hiring an all-terrain wheelchair might be possible in some cases, but needs to be done under the instruction of the intended user to ensure it is appropriate for their requirements. It is worth noting the observer-participant's all-terrain wheelchair and supporting vehicle cost tens of thousands of pounds and was not the simple type of all-terrain wheelchair available for hire.

\subsection{Tablets}

All students had the option of trying the tablets in the field. Students with ASD found the tablets helped with lack of physical co-ordination and gave them confidence to write/sketch, as it was easy to delete something if it was wrong. They found the tablets less distracting than paper notebooks or handouts as there was "nothing flapping" (also Sect. 6.2). For other students the experience was more varied. While some appreciated the potential benefits offered by tablets, others preferred notebook and pencils: either the tablet was another weighty item to carry and they were concerned about breaking them, or they found them frustrating and non-intuitive to use. We recommend students become familiar with tablets and apps prior to going into the field for them to be useful.

\subsection{Alternative exercises}

Only a small number of the planned alternative exercises were needed. All participants were able to go out into the field for the whole of each day, and concerns about vehicular access to localities did not materialise. However, the alternative material was successfully integrated into the field activity: outcrop photographs were combined with using the two-way radios to allow those in the four-wheel drive vehicle to hear and ask questions during the group discussions at the specific locations from which the photographs originated. At one locality, where the outcrop was heavily covered by seaweed, those in the vehicle were able to provide a rock description from their polished hand specimens for the entire group via a radio discussion.

As there were good interactions between all participants, it was soon discovered those in the vehicle had additional material (particularly the polished hand specimens). This en- couraged other students to approach the vehicle when it was nearby, thus enhancing interactions and leading to productive discussions centred on the vehicle with comparisons made between what could be seen at outcrop versus the details of the polished samples. So, whilst the planned evening work did not take place (Sect. 6.1), the materials provided fulfilled their purpose in allowing those unable to reach the outcrops to bring unique information to the group.

\subsection{Live feed system}

The live feed system worked very well, providing real time footage and enabling two-way conversations between those at the outcrop and those in the four-wheel drive vehicle. Generally, the transmitter for the live feed system needed to be in direct line of sight and within a few hundred metres of the receiver in the vehicle. In several cases, it was possible to set up a relay to extend its range. However, the system could not be used at every locality, and, where it could be used it was time- and personnel-intensive to set up to achieve the required geometry. For sites with sufficient network connectivity using apps such as Facebook Messenger or FaceTime would be a simple alternative.

The two-way radios used to communicate with the fourwheel drive vehicle worked well, allowing conversations with those in the vehicle in addition to the one-way feed from the field with the tour guide system.

\subsection{Virtual landscape}

Our initial plan was for half of the group to physically map the geology of Rhoscolyn and for half to map the virtual landscape version, allowing a comparison between the two experiences and the potential to improve the virtual one.

However, heavy rain on the day prevented any field activities. Instead the entire group used the rock samples, thin sections and associated exercises, alongside the virtual landscape exercise. For the virtual landscape this involved participants working in pairs, one student having already undertaken field mapping training during their undergraduate studies and the other not. This encouraged peer-teaching and discussions on different approaches to the exercise. Given the knowledge gained by those in the four-wheel drive vehicle from previously working on the alternative exercises, these materials provided an equitable platform for the sharing of diverse observations and interpretations of the material and led to wider ranging discussions and sharing of experiences, again greatly aiding in making those students feel integrated and valued.

\section{Post-course reflections and lessons learnt}

Overall, the design of the field course successfully enabled the intended learning outcome of establishing a model for the geological evolution of Anglesey to be achieved at a group 
level. Everyone was able to visit or experience each locality and a strong group bond developed which has continued for many participants beyond the end of the field course. From an instructor's point of view there were two key lessons: (1) to listen to the students, particularly those with disabilities, and respond to their input; and, (2) to be aware of making unconscious decisions about what someone with a disability can or cannot do, and instead to ask them.

Some aspects of the course were, by its very nature, not typical of a "normal" field course:

- All participants were self-selecting;

- Half of the students identified as having a disability (a far higher ratio than in most student cohorts);

- We had not met the students before the course, which made exact needs harder to evaluate;

- The students had in many cases not met each other before the course;

- The necessary technology and associated technical support were readily available on-site.

- The field course was new and, although Anglesey was known to the team, the work involved in setting it up was greater than would be required to add adjustments to an existing course.

- However, the most effective mitigations were the simplest, and benefitted the whole group:

- Good communication of detailed information both before and during the field course, which allowed participants to feel in control of their situation and thereby reduced anxiety;

- Alternative exercises, which not only allowed those unable to visit the outcrops to contribute unique data to a group, but also formed the basis of engaging and relevant wet weather activities;

- The focus on formative feedback rather than summative assessment

On this field course there were two instructors and two teaching assistants for thirteen students. This is above average staff to student ratio on UK field courses of between approximately $1: 12$ and $1: 20$. However, teaching was just one strand of this field course, and the level of in-field management required to coordinate the technical, teaching, health and safety and pastoral requirements of two groups (one at the outcrop and one nearby in the four wheel drive vehicle) was greater than anticipated, and an additional instructor to help deliver the field teaching would have been beneficial. Where a four-wheel drive vehicle is needed as a mobile classroom for a student with a mobility disability, we would recommend a dedicated driver/teaching assistant and a staff to student ratio that allows an instructor time to move between the main group and the vehicle.

Access Anglesey was run as a one-off field course created over a limited time period, as such the work to set it up was significant, including several field visits to collect specimens, photographs, assess access etc. However, for an existing course, material would already be available, and knowledge of the area established. The creation of alternative exercises requires some thought and effort; however, these resources will then be available each time the course runs. They also benefit the whole cohort in providing ready-made wet weather activities.

The role of formative/summative assessment on a field course is a wider debate than can be discussed here. However, the positive response from students to the lack of summative feedback and the reasons they gave for this were such that we recommend consideration is given to the type of assessment required on a field course.

\section{Recommendations and conclusions}

From a field course leader perspective, the pedagogic aims were met. We were able to give a diverse cohort of students the opportunity to experience an inclusive field course. We were able to create conditions in which everyone came out into the field every day to work in a supportive environment; this was something several of the participants had not been able to do previously, and a few had not even thought possible. More participants were able to work directly at the localities than had been expected, and, overall, everyone was able to participate in the experience of the field course. Feedback on the course was very positive, particularly with regards to the social aspect of being able to bond with other geologists and to feel included. Table 2 shows key mitigations and how and why to make them.

\subsection{Towards more inclusive and accessible fieldwork - wider recommendations}

In terms of wider recommendations, it is key that instructors delivering field courses realise that mitigations to accommodate and include all students are possible and desirable. This requires a degree of experience, and perhaps training, to enable staff to feel confident in offering students with disabilities a field course experience that works for them. Equally, to deliver such a field course requires sufficient material support from educational institutions to enable an inclusive course to be delivered. This ranges from the purely administrative - allowing sufficient workload time to devise, plan and deliver a field course - to the practical and the monetary - providing sufficient, trained staff and demonstrators and allowing the hiring of support vehicles or tour-guide systems. Some of the mitigations that have been employed here can be of utility for an entire cohort, as demonstrated with the successful use of 
Table 2. Key mitigations and how and why to make them.

\begin{tabular}{|c|c|c|}
\hline What & How & Why \\
\hline $\begin{array}{l}\text { Detailed pre-course communications: } \\
\text { Logistics, overall schedule, what to ex- } \\
\text { pect and what will be expected of par- } \\
\text { ticipants, intended outcomes, info on } \\
\text { the areas visited etc. }\end{array}$ & $\begin{array}{l}\text { E.g. meeting, handouts /information } \\
\text { sheets, website, as appropriate. Include } \\
\text { relevant links e.g. lodgings, locality } \\
\text { (e.g. use Google Earth and Streetview) } \\
\text { and use more than one format (verbal } \\
\text { and written). }\end{array}$ & $\begin{array}{l}\text { Encourages active involvement by re- } \\
\text { ducing fear of the unknown. Allows } \\
\text { participants to make plans and prepara- } \\
\text { tions. }\end{array}$ \\
\hline In field handouts: & $\begin{array}{l}\text { Portable, weatherproof guides includ- } \\
\text { ing detailed briefing info and ques- } \\
\text { tions to be considered at each locality } \\
\text { - information usually given in verbal } \\
\text { form only. Include electronic format for } \\
\text { tablets where appropriate. }\end{array}$ & $\begin{array}{l}\text { Encourages active involvement and } \\
\text { supplements parallel experiences by } \\
\text { giving verbal instructions in a writ- } \\
\text { ten format, allowing students to consult } \\
\text { these at any time. }\end{array}$ \\
\hline Alternative exercises & $\begin{array}{l}\text { Build on exercises done in the field and } \\
\text { include materials unique to the exercise }\end{array}$ & $\begin{array}{l}\text { Parallel experiences that include every- } \\
\text { one in the field experience and useful } \\
\text { inclement weather exercises for all. }\end{array}$ \\
\hline Reduce/remove summative assessment & $\begin{array}{l}\text { Consider formative feedback instead } \\
\text { and/or move summative work to after } \\
\text { the course. }\end{array}$ & $\begin{array}{l}\text { Encourages active involvement by al- } \\
\text { lowing participants to engage with the } \\
\text { field experience rather than feeling } \\
\text { pressured to focus on the answer for an } \\
\text { assessment. }\end{array}$ \\
\hline
\end{tabular}

the tour guide system, and such equipment might be considered as an aid to field teaching more generally, especially on courses where there is an extensive degree of in-field debrief required.

There remain questions around staff training. Internal surveys of staff at the University of Leeds made during the project highlighted field-teaching staff have low confidence to deal with students that have disabilities, specific learning difficulties or mental health conditions. This centres upon a lack of training available for staff to feel confident in difficult scenarios and the tensions of having to focus on one student's needs to the potential exclusion of other students, which can compromise fieldwork safety. In such crisis situations, there is a tendency to default to the safest option, which may require removing that student (or all students) from the field. Disability and neuro-diversity inclusion training delivered within a university's Equality and Inclusion Framework would increase staff confidence in integrating all students in fieldwork. Students with specific needs are often best placed in knowing the mitigations required, and staff should ask and actively listen to student concerns. Simple mitigations in these scenarios are to do with adequate resourcing of field courses in terms of staff support - allowing extra staff availability to be able to step in with particular students, for example - and to allow sufficient time before courses to plan viable alternative materials and approaches.

\subsection{Future aims}

Designing and delivering an inclusive field course was very useful to demonstrate mitigations and show that offering parallel educational experiences is possible. There remain particular challenges that this project was not able to address. Firstly, diversity and inclusivity training would ensure staff are better prepared. Secondly, the need for adequate resources to enable reasonable adjustments. Some challenges are materially hard for an institution to meet. The provision of an all-terrain wheelchair, for example, would have enabled students with mobility disabilities much improved access to the field areas, and a much more typical field experience. The costs and personal customisations required to supply such equipment are expensive, and there seems to be no wider provision from government to finance student access to such mitigations. Thirdly, accessing how institutional requirements for assessment affect a student's willingness and ability to learn. Formal assessments may provide a means of motivation or a source of stress. Lastly, the practicalities of scaling this bespoke trip to a field course with $>100$ participants, adapting to local practices and circumstances. The relatively widely scattered nature of certain disabilities among student cohorts may make mitigation harder at the local scale. Whether a sectoral-level response is required is a strategic decision left to bodies operating at a national level within higher education and in collaboration with professional associations. 
Data availability. No data sets were used in this article.

Author contributions. All authors were involved with the organisation and delivery of the field class, with JJH co-ordinating organisation, planning and logistics with support from BC, CEG and KW. DJM assisted with preparing of materials and field delivery. TDC was specifically involved with field broadcast and transmission technologies and acknowledges the legacy of the Open University ERA project in making this deployment possible. AS and CLA assisted with the transport logistics and had in-field roles of evaluating the effectiveness of the field class and conducted interviews with participants. For the write up all authors contributed to the first draft and in finalising the manuscript, co-ordinated by $\mathrm{JJH}$ as the main author.

Competing interests. The authors declare that they have no conflict of interest.

Special issue statement. This article is part of the special issue "Diversity and equality in the geosciences (EGU2019 EOS6.1 \& US4, AGU2018 ED41B, JpGU2019 U-02)". It is a result of the AGU Fall Meeting 2018, Washington, United States, 10-14 December 2018.

Financial support. The work detailed in this paper arose as a component of the project Embedding and Sustaining Inclusive STEM Pedagogies funded by the UK Government Office for Students (OfS) through its predecessor body, the Higher Education Funding Council for England (HEFCE).

Review statement. This paper was edited by Katherine Richardson and reviewed by Sarah Cornell and one anonymous referee.

\section{References}

AGI Disability Consensus Statement: https: //www.americangeosciences.org/community/ disability-consensus-statement, last access: 11 December 2019.

Boyle, A., Maguire, S., Martin, A., Milsom, C., Nash, R., Rawlinson, S., Turner, A. Wurthmann, S., and Conchie, S.: Fieldwork is Good: the Student Perception and the Affective Domain, J. Geogr. Higher Ed., 31, 299-317, https://doi.org/10.1080/03098260601063628, 2007.

Butler, R.: Teaching Geoscience through Fieldwork, GEES Teaching and Learning Guide, HE Academy Subject Centre for Geography, Earth and Environmental Science, 2008.

Gilley, B., Atchison, C., Feig, A., and Stokes, A.: Impact of inclusive field trips, Nature Geosci., 8, 579-580, https://doi.org/10.1038/ngeo2500, 2015.

Greenly, E.: The Geology of Anglesey, Memoir (District) Geological Survey of Great Britain HMSO, London, 982 pp., 1919.

Hall, T. and Healey, M.: Disabled students' experiences of fieldwork, Area, 37, 446-449, https://doi.org/10.1111/j.14754762.2005.00649.x, 2005.

Hocking, C.: Inclusive learning and teaching in higher education: a synthesis of research, available at: https://www.advancehe.ac.uk/knowledge-hub/inclusive-learning-and-teachinghigher-education-synthesis-research (last access: 10 August 2020), 2010.

Houghton, J., Lloyd, G. E, Robinson, A., Gordon, C. E., and Morgan, D. J.: The Virtual Worlds Project: geological mapping and field skills, Geol. Today, 31, 227-231, 2015.

Stokes, A. and Boyle, A. P.: The undergraduate geoscience fieldwork experience: Influencing factors and implications for learning, GSA Special Papers, 461, 291-311, https://doi.org/10.1130/2009.2461(23), 2009.

Stokes, A., Feig, A. D., Atchison, C. L., and Gilley, B.: Making geoscience fieldwork inclusive and accessible for students with disabilities, Geosphere, 15, 1809-1825, https://doi.org /10.1130 /GES02006.1, 2019.

UK Government Equality Act: http://www.legislation.gov.uk/ ukpga/2010/15/contents, last access: 17 December 2019.

Whitmeyer, S. J., Mogk, D. W., and Pyle, E. J.: An introduction to historical perspectives on and modern approaches to field geology education, in: GSA Special Papers, 461, vii-ix, 2009. 